\title{
ORIENTAÇÕES EDITORIAIS E CONTACTOS
}

O QUÍMICA - Boletim da Sociedade Portuguesa de Química versa todos os assuntos relacionados com a Química, e em particular os que dizem respeito à Química em Portugal.

Neste Boletim publicam-se entrevistas, reportagens, artigos solicitados e propostos, noticiário, recensões de livros e outras publicações e correspondência dos leitores. É incentivada a submissão voluntária de manuscritos de caráter relativamente geral e escritos de modo a despertar interesse a um vasto leque de leitores.

O QUÍMICA, embora não sendo especializado na História e Filosofia da Química, encoraja a submissão de contribuições nesta área, podendo também incluir artigos de autores especialmente convidados para publicarem sobre temas específicos deste domínio.

Normas de Colaboração e Instruções para os Autores

1. Os manuscritos devem ser enviados por correio eletrónico para o endereço bspq@ua.pt, dirigidos ao Editor do QUíMICA. O material submetido deverá conter o seguinte:

a. Um arquivo MS Word com as figuras e tabelas incorporadas. O texto deve ser escrito com espaçamento duplo. Tabelas, gráficos e ilustrações devem ser numerados e incorporados com as respetivas legendas descrevendo sumariamente o seu conteúdo. As citações longas devem ficar destacadas no texto; as curtas devem ser colocadas entre aspas.

b.Um arquivo adicional devidamente identificado, por cada gráfico ou ilustração, em formato JPEG ou TIFF, com a resolução adequada a uma boa reprodução gráfica no tamanho original.

2. Os manuscritos devem ser escritos em português e usando as regras de escrita do Acordo Ortográfico da Língua Portuguesa de 1990. Em casos especiais, sujeitos à concordância da Comissão Editorial do QUÍMICA, as contribuições poderão ser publicadas em inglês, ou noutra língua estrangeira, devendo então conter um resumo em português.

3. Os manuscritos devem conter um resumo em português e outro em inglês (50 a 200 palavras) com a descrição do respetivo conteúdo; igualmente o título deverá ser em português e em inglês. Salvo casos excecionais, os textos não devem exceder cerca de 30000 carateres.

4. Os manuscritos devem seguir, tanto quanto possível, as recomendações da IUPAC quanto à nomenclatura e unidades.

5. As referências devem ser numeradas sequencialmente à medida que sejam citadas ao longo do texto e indicadas por um número colocado entre parênteses retos (por exemplo: [1] ou [2,3] ou [4-8]). As referências devem ser compiladas no fim do texto, obedecendo aos seguintes formatos: a) Livros e capítulos de livros:

[1] S.J. Formosinho, “Fundamentos de Cinética Química”, Fundação Calouste Gulbenkian, Lisboa, 1982.

[2] R.S. Turner, University Reformers and Professional Scholarship in Germany, 1760-1806, in L. Stone (ed.), “The University in Society”, Princeton University Press, Princeton, 1974, 495-531.

[3] R.S. Turner, op. cit., 496-497.

b) Artigos em publicações periódicas:

[4] J.F. Hartwig, J. Am. Chem. Soc. 138 (2016) 2-24.

[5] A.N.L. Lopes, J.G. Ferreira, Anal. Biochem. 342 (2005) 195-197.

c) Endereços eletrónicos:

A utilização de endereços eletrónicos deve ser evitada e limitada a fontes institucionais fidedignas. A referência deve conter o endereço completo, de modo a permitir a localização da fonte, e a data de acesso.

[6] Spectral Database for Organic Compounds (SDBS): http://sdbs.db.aist.go.jp/sdbs/cgi-bin/cre_index.cgi (acedido em 24-10-2016).

d) Fontes manuscritas:

As fontes manuscritas devem conter todas as informações necessárias que permitam a sua localização; referências posteriores devem citar nome, data e abreviatura da fonte, caixa, número da página ou fólio:

[7] Carta de Adolphe Wurtz a Jean-Baptiste Dumas, 15 de fevereiro de 1864, Paris, Archives de l’Académie des Sciences, Dossier Wurtz. 6. Os agradecimentos devem ser colocados no fim dos artigos, antes das referências.

7. O corpo editorial acusará a receção das colaborações propostas e os textos serão apreciados por um ou mais avaliadores. Com base nas apreciações obtidas, será decidida a aceitação, a recusa ou eventualmente a revisão dos textos pelos autores antes de ser tomada uma decisão definitiva.

8. Os manuscritos submetidos para publicação no QUíMICA não podem ser submetidos a outras revistas. A reprodução de figuras já publicadas carece da devida autorização pelo detentor dos direitos. A autorização para reproduzir imagens é inteiramente da responsabilidade do autor, o que deverá ser referido nos casos em que se aplique.

9. Os direitos de autor dos artigos publicados são propriedade da Sociedade Portuguesa de Química, não se autorizando a sua reprodução total ou parcial, mesmo sob a forma de tradução numa língua diferente, salvo com autorização escrita da Comissão Editorial.

10. No caso dos autores desejarem corrigir as provas dos textos aceites para publicação, deverão indicá-lo expressamente aquando da submissão do manuscrito.

11. As provas tipográficas dos artigos em coautoria serão enviadas para o autor correspondente, a menos que o Editor seja informado do contrário. 12. A inobservância de qualquer das normas de colaboração poderá levar à devolução do texto recebido.

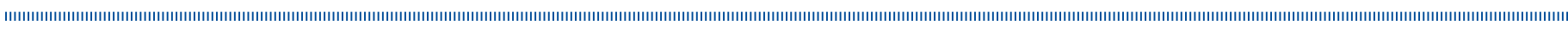

\section{Contactos:}

Editor do QUÍMICA - Boletim da Sociedade Portuguesa de Química: Augusto Tomé

Departamento de Química, Universidade de Aveiro, 3810-193 Aveiro

Tel.: 234370 712; E-mail: bspq@ua.pt 